\title{
液体誘電体中の二次元電界測定装置
}

\author{
准員田中克 英 (武蔵工大) \\ 正員高田達雄 (武蔵工大)
}

\section{Measurement System for Two-Dimensional Electric Field Vector in Dielectric Liquids}

Katsuhide Tanaka, Associate, Tatsuo Takada, Member (Musashi Institute of Technology)

Kerr electro-optic technique is an excellent method for the measurement of electric field distribution in dielectric liquids as it does not disturb the original electric field distribution. However this method is not suitable to an insulating liquid with a small Kerr constant such as an insulating transformer oil. For this reason, our group has developed a high sensitive measurement system of electric field strength by using the combined technique of an electric field modulation and an elliptically polarized incident light. This method has been applied to measure the uniform electric field distribution (only the electric field intensity) in a liquid.

A new measurement system has been recently developed to measure a non-uniform electric field distribution (electric field intensity and its direcion). This paper describes the measuement principle of two-dimensional electric field vector in dielectric liquids. Some results of electric field vector distribution in a composite solid-liquid electrical insulation are presented to demonstrate the effectiveness of the technique.

The main points are shows as follows:

(1) The theoretical equation for measuring the electric field vector is derived for the optical system which consists of a laser, a polarizer, a quarter-wave plate, a test cell (non-uniform electric field), a non-polarizing beam splitter, two analyzers and two photo-detectors.

(2) The effectiveness of the technique is confirmed by comparing the theoretical values with the experimental results. Furthermore the electric field vector distributions of the transformer oil in a compound insulation system of liquids and solids are measured.

$$
\text { キーワード：電気光学カー効果, 液体誘電体, 電界測定, 電界ベクトル, 無偏光ビームスプリッタ }
$$

\section{1.はじめに}

交流-直流変換用の変圧器は液体-固体の複合絶縁系 で構成されている。この複合絶縁系には交流に直流が 重疊され，直流特有の現象である電荷の注入，不純物 からのキャリヤ生成，その移動や蓄積などが起こる。 その結果, 液体-固体界面に電荷が蓄積するため, 電 界が局部的に強調され絶縁破壤電圧を大きく低下させ ることがある。界面蓄積電荷が原因で, 初期の設計電 界と異なった電界分布となる。このように, 直流絶縁
設計には交流絶縁設計にみられない蓄積電荷効果を考 慮しなくてはならない。従って, 絶縁設計技術者は, 液体誘電体中の電界分布と蓄積電荷分布を直接観察し てその特性を理解する必要がある。液体誘電体内の内 部電界を乱すことなく電界強度を測定する方法に電気 光学カー効果によるものがある。しかし, カ一効果に よる縞模様写真撮影法(1)は, 一般に感度が覀く(変圧 器油中で電極長 $1 \mathrm{~m}$ の場合の測定下限は $10^{5} \mathrm{~V} / \mathrm{cm}$ 程 度), 短電極長で低電界の測定には適していない。そ こで,これまでに電界変調と入射楕円偏光を用いた, 
液体誘電体中の電界強度湘定装置の開発が行われてき $た^{(2)}$ 。この測定装置により，平行平板電極間の液体誘電 体中の高感度 (変圧器油中で電極長 $8 \mathrm{~cm} の$ 場合の測 定下限 $100 \mathrm{~V} / \mathrm{cm}$ ) な平等電界測定が可能となった。

実際の電力機器では液体誘電体を不平等電界下で用 いることが多く, 液体諉電体中の電界はその强度も方 向も一定ではない。上述の高感度電界強度測定装置で は，不平等電界の強度と方向を測定することは困難で あった。

本論文は，改良した二次元電界べタトル測定装䈯の 原理とその特性を迹べ，代表的な不平等電界場の二次 元電界ベクトルの測定結果を紹介している。表 1 に, これまで報告されている三つの二次元電界ベクトル測 定装置の特幑示す。カー定数の小さい変圧器油中て の二次元電界ベクトルの測定には，(1) 感度の向上, (2)ガラス空の残留応力による複届折の除去，（3）電 界ベクトル（強度，方向）算出法の技術が必要であ

表 1 二次元電界ベクトル測定法の比較

Table 1. Techniques for two-dimensional electric field measurement.

\begin{tabular}{|c|c|c|c|}
\hline 薄入技術 & 模光子回転法 ${ }^{\{3\}}$ & 光位相変調法 ${ }^{40\rangle}$ & 2 ピーム法 \\
\hline (1) 感度の向上 & 電界変調 & 電界変調 & 電界变調 \\
\hline $\begin{array}{l}\text { (2) 測定用空ガ } \\
\text { ラスの残留 } \\
\text { 応力歪の除 } \\
\text { 去 }\end{array}$ & 円偏光 & $\begin{array}{l}\text { 椅円偏光 } \\
\text { (光位相変調器) }\end{array}$ & $\begin{array}{l}\text { 棈円偏光 } \\
\text { (位柏差 } \alpha=45^{\circ} \\
\text { に固定) }\end{array}$ \\
\hline $\begin{array}{c}\text { （3）電界ベクト } \\
\text { ルの算出 }\end{array}$ & $\begin{array}{l}\text { 桧光子D機械的 } \\
\text { 回転 }\end{array}$ & $\begin{array}{l}\text { 光位相変調器 } \\
1 \text { ビーム透過光 } \\
\text { 検出 }\end{array}$ & $\begin{array}{l}\text { 無编光ビームス } \\
\text { プリッタ } \\
2 \text { ビーム透過光 } \\
\text { 険出 }\end{array}$ \\
\hline
\end{tabular}

る。三つの測定法の特徴は，電界ベクトルを算出する ために，(i)検光子を機械的に回転する方法(3)，(ii) 光位相変調器を導入する方法(1)，(iii) 検出光を 2 ビー ムに分離する方法である。2ビーム法は簡単な光学系 で，機械的駆動部がないので温度的にも時間的にも安 定した測定ができる特徴をもっている。

前報の光位相変調法 ${ }^{(4)}$ を，2ビーム法に改良した点 を次に述べる。兩者とも，感度向上のために直流電界 に変調電界を重畳した電界変調法を採用している。前 報の光位相変調法は, 光位相変調器の温度変化に対す る不安定性および光学系の光軸合せが困難であり，そ の操作は不便であった。光位相変調器の使用目的は, 電界の強度と方向を貺定するために二つの入射偏波面 を作るためであった。本論文の 2 ビーム法は，無偏光 ビームスプリッタを採用することにより，テストセル からの透過光を二つのビームに分け，それぞれ異なっ た透過光軸の透過光強度を測定している。この透過光 強度の測定から，電界の強度と方向を算出している。 以下に 2 ビーム法の測定原理を述べる。

\section{2. 電界ベクトル測定の原理}

〈2-1〉液体誘電体中の電界ここご，注意すべ きことは，液体誘電体中に空間電荷が存在しない場合 は, 直流電界と変調電界の方向姑一致しているが，架 間電荷が存在する場合, 直流電界の方向は空間電荷の 影響により変調電界の方向と異なっていることであ る。従って, 液体誘電体中の電界は, 直流電界ベクト ル $\left(E_{\mathrm{DC}}, \phi_{\mathrm{DC}}\right)$ と変調電界ベクトル $\left(E_{\mathrm{AC}}, \phi_{\mathrm{AC}}\right)$ を合成し た電界ベクトル $\left(E, \phi_{E}\right)$ になる(4)。これらの関係はそ れぞれ(1)，(2)式で示される。

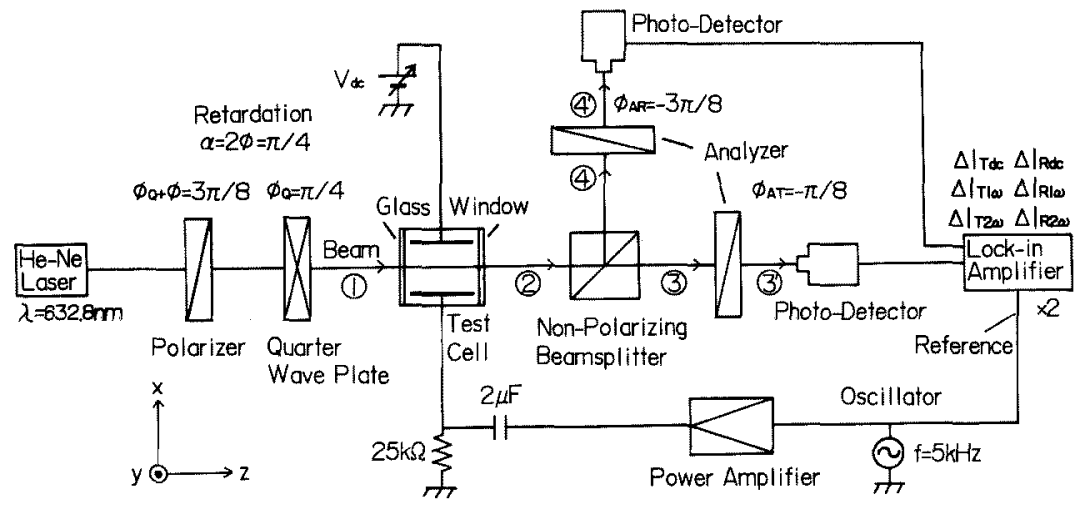

図 1 二次元電界ベクトル測定装置

Fig. 1. Schematic diagram of the experimental setup for two-dimensional electric field measurement. 

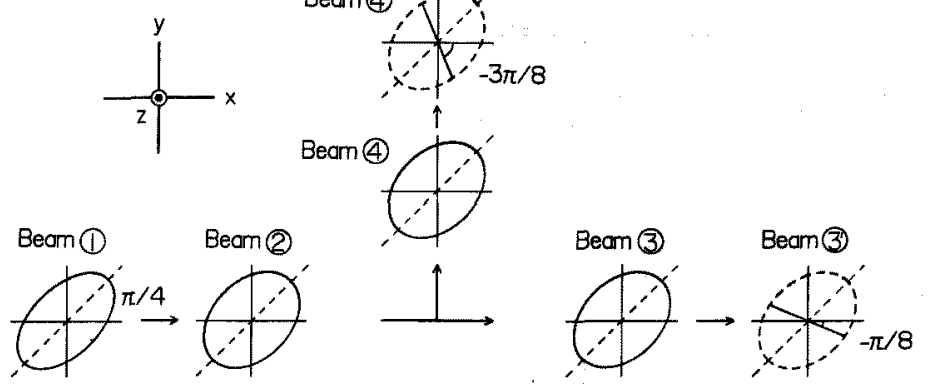

図 2 光学系の各部偏光状態

Fig. 2. Sketch of elliptically polarized light wave at each position of optical experimental system.

$E=\left\{\left(E_{\mathrm{DC}} \sin \phi_{\mathrm{DC}}+E_{\mathrm{AC}} \sin \omega t \sin \phi_{\mathrm{AC}}\right)^{2}\right.$

$\left.+\left(E_{\mathrm{DC}} \cos \phi_{\mathrm{DC}}+E_{\mathrm{AC}} \sin \omega t \cos \phi_{\mathrm{AC}}\right)^{2}\right\}^{1 / 2}$

$\phi_{E}=\tan ^{-1} \frac{E_{\mathrm{DC}} \sin \phi_{\mathrm{DC}}+E_{\mathrm{AC}} \sin \omega t \sin \phi_{\mathrm{AC}}}{E_{\mathrm{DC}} \cos \phi_{\mathrm{DC}}+E_{\mathrm{AC}} \sin \omega t \cos \phi_{\mathrm{AC}}}$

《2・2〉光学系の基本構成 2 ビーム法の二次元 電界ベクトル測定装置の構成図を図 1 に示す。テスト セルは電極を配置し変圧器油を満たしたもので, 直流 電界に変調電界が重畳されている。 He- Neレーザか らの光ビームを, 偏光子と $1 / 4$ 波長板より位相差 $\alpha=$ $45^{\circ}$ の棈円偏光にしてテストセルに入射する(1)。この 值は，ガラス空の残留応力に起因する位相差約 $\pm 0.2^{\circ}$ よりも十分大きく選んだ(2)。光がテストセルを 透過するとき電気光学カー効果により, 更に位相差を 増し楕円になる(2)。検光子を回転することなく電界べ クトルを測定するために，無偏光ビームスプリッタに より光を分路する(3)(4)。これらの光に対して透過側 $(T)$ の検光子 $\left(\phi_{A T}\right)$ と反射側 $(R)$ の検光子 $\left(\phi_{A R}\right)$ を設 置し, 二つの透過光強度を測定している。光学系各部 の偏光状態を図 2 に示す。

〈2.3〉 光学系の透過光強度 入射光と透過光の 電界波の関係を導く。図 1 の光学系において, 偏光子 の透過光軸を $\left(\phi_{Q}+\phi\right), 1 / 4$ 波長板の進相軸を $\phi_{Q}$, 力 一効果により発生した位相差を $\Delta \theta\left(=r E^{2}, E\right.$ は電界 強度), 電界方向を $\phi_{E}$, 検光子の透過光軸を $\phi_{A}$ とす ると, 全光学系を透過した光の電界波成分 $\left(e_{x}, e_{y}\right)$ と 入射光の電界波成分 $\left(e_{x 0}, e_{y 0}\right)$ の関係は $(3)$ 式のよう にジョーンズマトリックスで示すことができる。ただ し, $r=2 \pi B L$ であり, $B$ は液体誘電体のカ一定数, $L$ は実効光路長であり電極長にほほ等しい。

$$
\begin{aligned}
\left(\begin{array}{l}
e_{x} \\
e_{y}
\end{array}\right)= & \left(\begin{array}{ll}
\cos ^{2} \phi_{A} & \cos \phi_{A} \sin \phi_{A} \\
\cos \phi_{A} \sin \phi_{A} \sin ^{2} \phi_{A}
\end{array}\right) \\
& \times\left(\begin{array}{l}
\cos ^{2} \phi_{E}+\sin ^{2} \phi_{E} e^{-j \Delta \theta} \\
\cos \phi_{E} \sin \phi_{E}\left(1-e^{-j \Delta \theta}\right)
\end{array}\right) \\
& \left.* \begin{array}{l}
\cos \phi_{E} \sin \phi_{E}\left(1-e^{-j \Delta \theta}\right) \\
\sin ^{2} \phi_{E}+\cos ^{2} \phi_{E} e^{-j \Delta \theta}
\end{array}\right) \\
& \times\left(\begin{array}{l}
\cos ^{2} \phi_{Q}-j \sin ^{2} \phi_{Q} \\
\cos _{Q} \sin \phi_{Q}(1+j)
\end{array}\right. \\
& \left.* \begin{array}{l}
\cos \phi_{Q} \sin \phi_{Q}(1+j) \\
\sin ^{2} \phi_{Q}-j \cos \phi_{Q}^{2}
\end{array}\right) \\
& \times\left(\begin{array}{l}
\cos ^{2}\left(\phi_{Q}+\phi\right) \\
\cos \left(\phi_{Q}+\phi\right) \sin \left(\phi_{Q}+\phi\right)
\end{array}\right. \\
& \left.* \begin{array}{l}
\cos \left(\phi_{Q}+\phi\right) \sin \left(\phi_{Q}+\phi\right) \\
\sin ^{2}\left(\phi_{Q}+\phi\right)
\end{array}\right)\left(\begin{array}{l}
e_{x 0} \\
e_{y 0}
\end{array}\right)
\end{aligned}
$$

(3) 式で示されるマトリックスを演算して, 透過光の 電界波 $\left(e_{x}, e_{y}\right)$ を求める。そして, これらの光電界波は (4)，（5）式によって光強度に変換される。ただし， $Z_{0}$ は真空の特性インピーダンスである。

$$
\begin{aligned}
& \Delta I=\frac{1}{T} \int_{0}^{T} \frac{e_{x}^{2}+e_{y}^{2}}{Z_{0}} d t \\
& I_{0}=\frac{1}{T} \int_{0}^{T} \frac{e_{x 0}{ }^{2}+e_{y 0}{ }^{2}}{Z_{0}} d t
\end{aligned}
$$

また, $\gamma$ は電極長 $L=8 \mathrm{~cm}$ で変圧器油 $(B=3.5 \times$ $\left.10^{-15} \mathrm{~m} / \mathrm{V}^{2}\right)$ の場合, およそ $\gamma \fallingdotseq 10^{-15} \mathrm{~m}^{2} / \mathrm{V}^{2}$ であるた め低電界領域て $\cos \left(\gamma E^{2}\right) \fallingdotseq 1, \sin \left(\gamma E^{2}\right) \fallingdotseq \gamma E^{2}$ の近似 
が成立する。従って, 透過光強度比 $\Delta I / I_{0}$ を算出する と(6)式になる。

$$
\begin{aligned}
\frac{\Delta I}{I_{0}}= & \frac{1}{2}+\frac{1}{2} \cos \alpha \cos 2\left(\phi_{Q}-\phi_{A}\right) \\
& +\frac{1}{2} \sin \alpha \gamma E^{2} \sin 2\left(\phi_{E}-\phi_{A}\right) \cdots \cdots(6)
\end{aligned}
$$

上式に，(1)，（2）式を代入して更に透過光強度比 $\Delta I / I_{0}$ を算出すると(7)式になる。

$$
\frac{\Delta I}{I_{0}}=\frac{\Delta I_{\mathrm{DC}}}{I_{0}}+\frac{\Delta I_{1 \omega}}{I_{0}} \sin \omega t-\frac{\Delta I_{2 \omega}}{I_{0}} \cos 2 \omega t
$$

ただし，直流成分，基本波成分，第二調波成分の透過 光強度比はそれぞれ( 8$) \sim(10)$ 式で示される。

$$
\begin{aligned}
\frac{\Delta I_{\mathrm{DC}}}{I_{0}}= & \frac{1}{2}\left\{1+\cos \alpha \cos 2\left(\phi_{Q}-\phi_{A}\right)\right\} \\
& +\frac{1}{4} \sin \alpha \gamma\left\{2 E_{\mathrm{DC}}{ }^{2} \sin 2\left(\phi_{\mathrm{DC}}-\phi_{A}\right)\right. \\
& \left.+E_{\mathrm{AC}}^{2} \sin 2\left(\phi_{\mathrm{DC}}-\phi_{A}\right)\right\} \cdots \cdots \cdots(8) \cdots(9) \\
\frac{\Delta I_{1 \omega}}{I_{0}}= & \sin \alpha \gamma E_{\mathrm{DC}} E_{\mathrm{AC}} \sin \left(\phi_{\mathrm{DC}}+\phi_{\mathrm{AC}}-2 \phi_{A}\right) \\
& \ldots \cdots \cdots \cdots \cdots \cdots \cdots \cdots \cdots \cdots \cdots \cdots \cdots \cdots \cdots \cdots \cdots \cdots \cdots \cdots
\end{aligned}
$$

また, 直流成分 $(8)$ 式の第 2 項目は第 1 項目に比べて 極めて小さいため無視できる。

〈2.4〉 2 ビーム法の透過光強度 測定したい量 は直流電界の強度と方向 $\left(E_{\mathrm{DC}}, \phi_{\mathrm{DC}}\right)$ および変調電界の 強度と方向 $\left(E_{\mathrm{AC}}, \phi_{\mathrm{AC}}\right)$ の四つである。しかし, 測定さ れる光強度は $(9) ，(10)$ 式の二つなので，二つの式か ら四つの量は算出できない。これらを求めるために検 光子の透過光軸 $\phi_{A}$ を 2 種類設定すれば, (9), (10) 式の二つは透過側の (12)，(13)式と，反射側の(15), (16)式に示す四つにすることができる。

透過側

$$
\begin{aligned}
& \frac{\Delta I_{\mathrm{TBC}}}{I_{0}}=\frac{1}{2}\left(1-\frac{1}{2} \cos \alpha\right) \\
& \frac{\Delta I_{T 1 \omega}}{I_{0}}=\sin \alpha \gamma E_{\mathrm{DC}} E_{\mathrm{AC}} \sin \left(\phi_{\mathrm{DC}}+\phi_{\mathrm{AC}}+\pi / 4\right) \\
& \frac{\Delta I_{T 2 \omega}}{I_{0}}=\frac{1}{4} \sin \alpha \gamma E_{\mathrm{AC}}{ }^{2} \sin 2\left(\phi_{\mathrm{AC}}+\pi / 8\right)
\end{aligned}
$$

反射側

$$
\frac{\Delta I_{R D C}}{I_{0}}=\frac{1}{2}\left(1-\frac{1}{2} \cos \alpha\right)
$$

$$
\frac{\Delta I_{R 1 \omega}}{I_{0}}=\sin \alpha \gamma E_{\mathrm{DC}} E_{\mathrm{AC}} \sin \left(\phi_{\mathrm{DC}}+\phi_{\mathrm{AC}}+3 \pi / 4\right)
$$

$$
\frac{\Delta I_{R 2 \omega}}{I_{0}}=\frac{1}{4} \sin \alpha \gamma E_{\mathrm{AC}}{ }^{2} \sin 2\left(\phi_{\mathrm{AC}}+3 \pi / 8\right)
$$

よって，これらの四つの式を連立することにより直流 電界の強度と方向 $\left(E_{\mathrm{DC}}, \phi_{\mathrm{DC}}\right)$ 扝よび変調電界の強度と 方向 $\left(E_{\mathrm{AC}}, \phi_{\mathrm{AC}}\right)$ の算出が可能となる。次に，2枚の検 光子の透過光軸 $\phi_{A T}$ と $\phi_{A R}$ の決定法について述べる。

〈2.5〉 検光子の透過光軸の決定 高感度平等電 界測定法 ${ }^{(2)}$ おるび光位相変調法 ${ }^{(4)} の$ 場合の, 検光子の 透過光軸 $\phi_{A}$ は棈円偏光の短軸成分である $\phi_{A}=-45^{\circ}$ の最適值に設定されていた。本装置では，2枚の検光 子の透過光軸 $\phi_{A T}$ と $\phi_{A R}$ を異なった角度に設定する 必要がある。(12)式の回転角 $\left(\phi_{\mathrm{DC}}+\phi_{A C}-2 \phi_{A T}\right)$ と (15) 式の回転角 $\left(\phi_{\mathrm{DC}}+\phi_{\mathrm{AC}}-2 \phi_{A R}\right)$ との間に $\pi / 2$ の差 を与えた。その理由は，互いに直交性をもたせること により電界方向によらず基本波成分の(12) と（15）式の 透過光強度が同時に雑音レベル以下になることはな く，どちらか一方は常に雑音レベル以上の值をとるこ とができるからである。また，第二調波成分の(13) 式 と(16)式の間でも同椂である。従って, $\phi_{A T}=-\pi / 8$, $\phi_{A R}=-3 \pi / 8$ の值を選んだ。

〈2・6〉電界べクトルの算出式上記の(12), (13)，(15)，(16)式加ら四つの光強度 $\Delta I_{T 1 \omega}, \Delta I_{T 2 \omega}$, $\Delta I_{R 1 \omega}, \Delta I_{R 2 \omega}$ をロックインアンプで測定することによ り次式の電界ベクトルが算出できる。ただし，(17)， (19)式にある $I_{0}$ は(11)または(14)式の直流成分から 得られる $I_{0}$ を使用している。

$$
\begin{aligned}
& E_{\mathrm{DC}}=\frac{\sqrt{\Delta I_{T 1 \omega^{2}}+\Delta I_{R 1 \omega}{ }^{2}}}{I_{0} \gamma \sin \alpha E_{\mathrm{AC}}} \ldots \ldots \ldots . . . \\
& \tan \left(\phi_{\mathrm{AC}}+\phi_{\mathrm{AC}}+\pi / 4\right)=\left(\frac{\Delta I_{T 1 \omega}}{\Delta I_{R 1 \omega}}\right) \\
& E_{\mathrm{AC}}=2\left(\frac{\Delta I_{T 2 \omega}+\Delta I_{R 2 \omega}{ }^{2}}{I_{0}{ }^{2} \gamma^{2} \sin ^{2} \alpha}\right)^{1 / 4} \ldots \ldots . \\
& \tan 2\left(\phi_{\mathrm{AC}}+\pi / 8\right)=\left(\frac{\Delta I_{T 2 \omega}}{\Delta I_{R 2 \omega}}\right) \ldots \ldots . .
\end{aligned}
$$

\section{3. 測定装置の基本特性}

〈3・1〉回転型テストセル 図 1 に示した湘定 装置が前章の基本式ど扔り動作していることを確認す るために，図 $3 に$ 示す回転型テストセルを使用した。 回転型テストセルはステンレス鋼製平行平板電極（ギ ヤップの長さ $d=5 \mathrm{~mm}$, 電極長 $L=8 \mathrm{~cm}$ ）で構成さ れ, 変圧器油で満たされている。そして, テストセル 


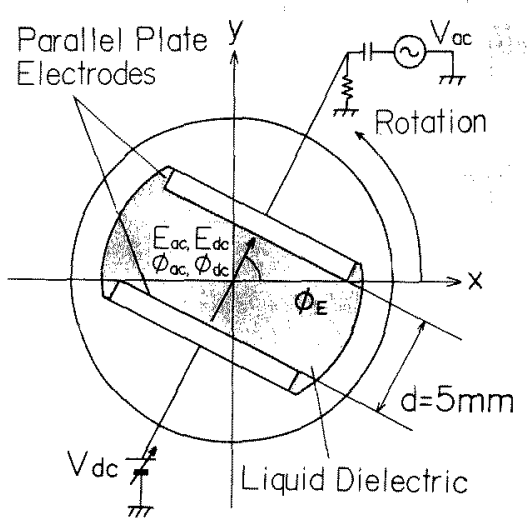

図 3 回転型テストセルの断面図

Fig. 3. Cross section of rotating electrode cell.

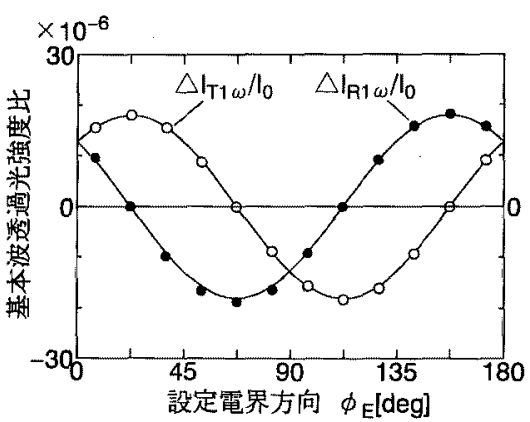

図 4 基本波成分の透過光強度比

Fig. 4. Experimental relationship between fundamental transmitted light intensity ratio and angle of applied electric field.

は光軸を中心に回転でき電界の方向 $\phi_{E}$ を任意に設定 できるようになっている。更に，印加電圧により内部 電界強度も可変できる。以下の確認実験は次の条件で 行った。直流電圧 $3 \mathrm{kV}$, 変調電圧 $V_{\mathrm{AC}}=300 \mathrm{~V}$ ピー クを印加し，テストセルを回転 $\left(\phi_{E}=0 \sim 180^{\circ}\right)$ させて 各々の回転角に枋ける透過強度を測定した。

〈3.2〉 透過光強度の特性 （12），(15)式に示す 基本波成分の透過光強度比の設定電界方向依存性を図 4 亿示す。また，(13)，(16)式に示す第二調波成分の 透過光強度比の設定電界方向依存性を図 5 に示す。た だし，テストセル内の電界は平等であるので，両図に おいて電界方向は $\phi_{E}=\phi_{\mathrm{DC}}=\phi_{\mathrm{AC}}$ として, 上式の透過 光強度比の計算結果を実線で示している。すべての測 定点牥計算結果とほほ一致している。

〈3.3〉 電界の強度と方向の特性直流電界強度 $E_{\mathrm{DC}}$ と変調電界強度 $E_{\mathrm{AC}}$ の設定電界方向依存性を図 6 に示す。平行平板電極内の直流電界および変調電界は

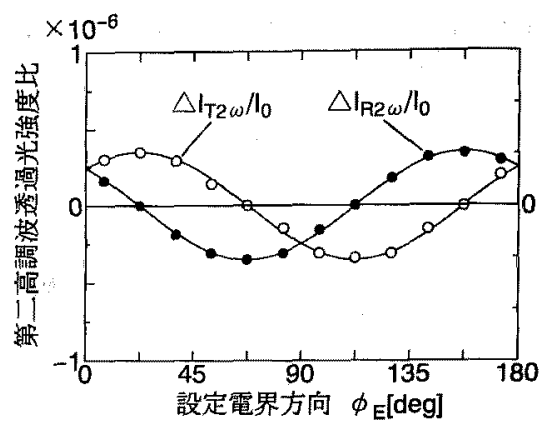

図 5 第二調波成行の透過光強度比

Fig. 5. Experimental relationship between 2nd harmonic transmitted light intensity ratio and angle of applied electric field.

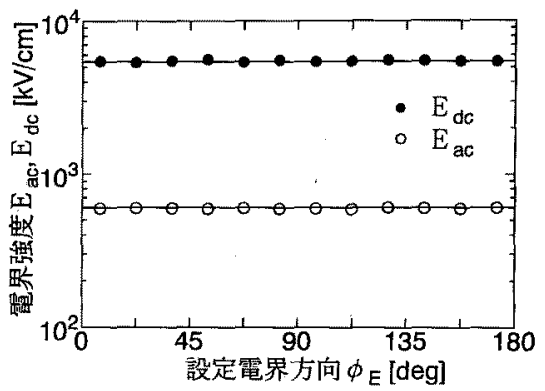

図 6 直流括よび変調電界強度の特性

Fig. 6. Dependence of $\mathrm{DC}$ and $\mathrm{AC}$ electric field intensity on the angle of applied electric field.

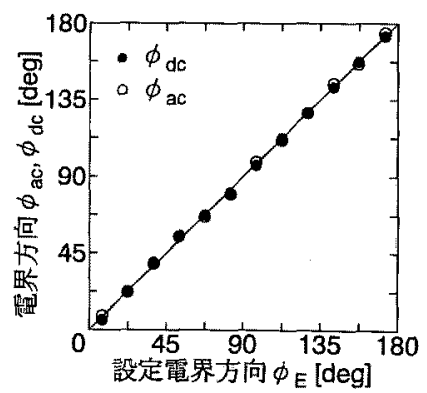

図 7 直流捛よび変調電界方向の特性 Fig. 7. Dependence of $\mathrm{DC}$ and $\mathrm{AC}$ angle of electric field on angle of applied electric field.

設定電界方向によらず一定であることが示されてい る。ただし，平均印加電界は $6 \mathrm{kV} / \mathrm{cm}$ であるが測定

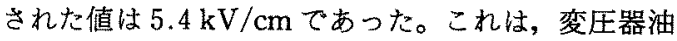
中の $6 \mathrm{kV} / \mathrm{cm}$ の印加電界によってへテロ空間電荷が 形成され，中央部の電界が弱められるためである(5)。 


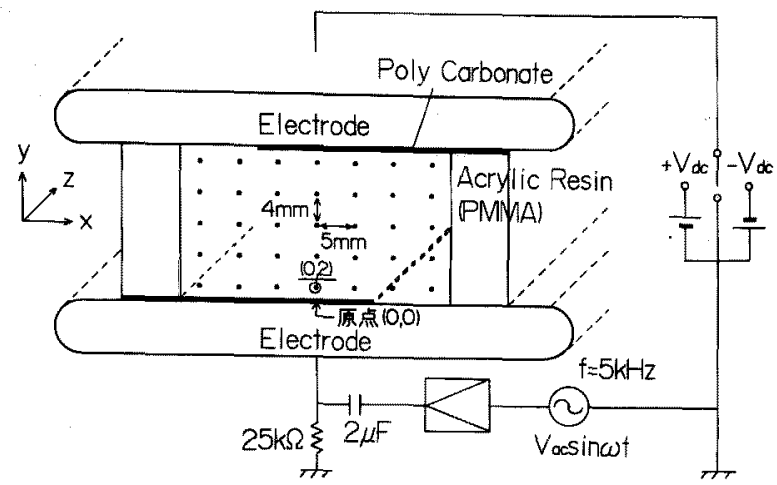

図 8 複合絶縁系テストセルの断面構造

Fig. 8. Schematic diagram of test cell for the composite insulation of solid-liquid.

また, 直流電界方向 $\phi_{A C}$ と变調電界 $\phi_{A C}$ の設定電界方 向依存性を図 7 に示す。測定された電界方向は設定電 界方向とよく一致している。

以上のように本測定装置は, 前節で誘導した理論式 どおりに動作していることが確認された。

\section{4. 不平等電界ベクトルの測定}

〈4・1〉複合絶縁系テストセル＼cjkstart液体-固体の複合 絶縁系において界面蓄積電荷に上る不平等電界場を測 定するために，図８に示す新たなテストセルを用意 した。このテストセルは，ステンレス鋼製の平行平板電 極 (ギャップの長さ $d=20 \mathrm{~mm}$, 電極長 $L=16 \mathrm{~cm}$ ) で構成され，双方の電極面に固体誘導体のポリカーボ ネート（厚さ $100 \mu \mathrm{m}$ の絶縁フィルム）を図のように 配置している。そして, テストセルは変圧器油で満た されている。2枚の電極はアクリル板 (PMMA) で 固定されている。以下の実験は次の条件で行った。直

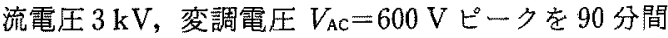
印加した後に電界測定を開始した。

〈4・2〉直流電界べクトルの測定結果図 9 亿直 流電界べクトル分布の測定結果を示す。測定された直 流電界ベクトル分布は，電界の強度と方向が場所によ って異なっている。これは，油中に存在している不純 物から発生した電荷がフィルム表面に蓄積され，この 蓄積電荷による電界が油中の電界をひずませているこ とを示している。すなわち，測定された電界は外部直 流印加電界々蓄積電荷による電界の合成されたものて ある。

〈4・3〉 変調電界ベクトルの測定結果 図 10 に変 調電界ベクトル分布の測定結果を示す。この結果は, 直流電界と変調電界が同時に印加されているときの変 調電界ベクトルを示している。空間電荷の存在にもか

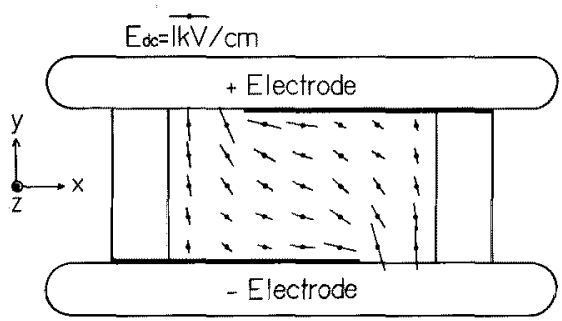

図 9 直流電界ベクトル分布

Fig. 9. Measured DC electric field vector distribution in transformer oil.

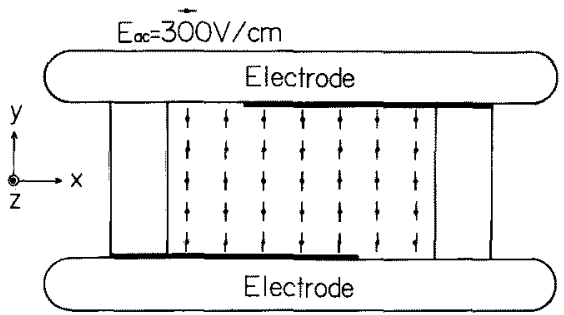

図 10 変調電界ベクトル分布

Fig. 10. Measured AC electric field vector distribution in transformer oil.

かわらず，変調電界ベクトルはすべて外部変調電界と 一致している。これは, 図 9 の蓄積電荷による直流電 界分布を得るのに 1 分以上の時間を要しているので, 蓄積電荷は変調周波数 $(5 \mathrm{kHz})$ に応答できないため である。

\section{5. まとめ}

液体誘電体中の電界ベクトル（強度, 方向）の測定 装置を改良することができた。本諭文で得られた成果 
を以下に述べる。

（1）直流電界の強度と方向, 変調電界の強度と方 向のそれぞれを測定するために無偏光ビームスプリッ 夕を採用し, 透過側と反射側のそれぞれの基本波成分 と第二調波成分を検出することを提案した。これを実 現する光学系を考案し, その透過光強度と液体誘電体 中に扔ける電界の強度と方向を結心゙関係式を誘導し た。

（2）本測定装置の基本特性を測定するために，光 軸を中心に電界の方向を設定できる回転型テストセル を用い, 透過光強度と液体誘電体中における電界の強 度と方向の関係を実験的に確認した。

（3）液体-固体複合絶縁系の界面に蓄積された電 荷による不平等電界場の測定に本装置を応用した。そ の結果, 蓄積電荷によるひずみ電界分布の測定ができ た。

終りに, 本研究の実験に協力してくれた本学卒業 生, 吉田尚代さん（現, 東芝）と藤沼一弘氏（現, ア ンリッ) と大串伸夫氏 (現, 雪印) に厚くお礼申し上 げます。また, 本研究の一部は文部省科学研究費 (No. 02045041) の支援により行われた。

(平成 5 年 3 月 1 日受付)

\section{文献}

(1) M. Zahn, T. Takada \& S. Voldman: "Kerr Electrooptic Field Mapping Measurements in Water using Parallel Cylindrical Electrodes", J. Appl. Phys., 54, 4746 (1983)

(2) T. Maeno \& T. Takada: "Electric Field Measurement in Liquid Dielectrics using Combination of ac Voltage Modulation and a Small Retardation Angle", IEEE Trans. Elect. Insulaition, EI-22, 503 (1987)
(3) Uno Gafvert: "Two Dimensional Measurements of Electric Fields in Transformer Oil", Annual Report of CEIDP, Pocono Manor, USA, p. 667 (1990)

(4) R. Liu, A. Satoh, T. Kawasaki, K. Tanaka \& T. Takada: "High-sensitivity Kerr-effect Technique for Determination of 2-dimensional Electric Fields", IEEE Trans. Elect. Insulation, EI-27, 245 (1992)

(5) Y. Nonaka, H. Sato, T. Maeno \& T. Takada: "Electric Field in Transformer Oil Measured with the Kerr-effect Technique", ibid., EI-26, 210 (1991)

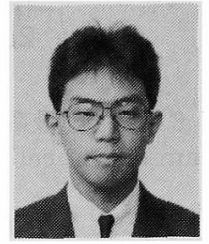

\section{田中克 英 (准員)}

昭和 42 年 12 月 21 日生。平成 3 年 3 月武藏工業大学工学部電気電子工学科卒 業。同年 4 月同大学大学院工学研究科電 気工学専攻入学, 現在に至る。液体誘電 体中の電界測定の研究に従事。

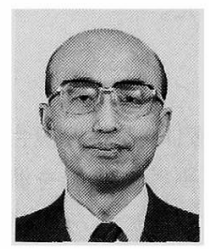

\section{高田 達 雄 (正員)}

昭和 14 年 8 月 8 日生。 38 年 3 月武藏 工業大学電気工学科卒業。 41 年 3 月東 北大学大学院工学研究科電気, 通信工学 専攻修士課程修了。 42 年 4 月武蔵工業 大学講師, 49 年 4 月同大学助教授, 61 年 4 月同教授、現 在に至る。工学博士。 56 年〜 58 年アメリカMIT 客員研 究員, 主として, 高分子誘電体中の電気伝導現象と空間䉓 荷測定技術の研究に従事。 49 年, 56 年電気学会論文賞受 賞。IEEE 会員。 